\title{
Effect of Firm's Information Dissemination Culture on Market Orientation: A Study in Tourism Sector
}

\author{
Atanu Adhikari \\ Indian Institute of Management Kozhikode (IIMK), Kozhikode, India \\ Email: atanu.adhikari@iimk.ac.in
}

How to cite this paper: Adhikari, A. (2018) Effect of Firm's Information Dissemination Culture on Market Orientation: A Study in Tourism Sector. Theoretical Economics Letters, 8, 1391-1400. https://doi.org/10.4236/tel.2018.87089

Received: January 27, 2018

Accepted: May 25, 2018

Published: May 28, 2018

Copyright $\odot 2018$ by author and Scientific Research Publishing Inc. This work is licensed under the Creative Commons Attribution International License (CC BY 4.0).

http://creativecommons.org/licenses/by/4.0/

Open Access

\begin{abstract}
Despite being highly relevant, research on different aspects of market orientation and its effects on tourism industry are limited. No literature thus far has examined intra-organizational learning on market orientation. Additionally, emerging economies (e.g., India) could be a key destination of tourism, other than a few exceptions, existing tourism literature has not paid enough attention to such markets. We examine the impact of intra-organizational learning on market orientation in tourism sector. We contribute by introducing and investigating the intra-organizational learning, based on capability-based theories of the firm. Using Structural Equation Modeling, we have investigated responses to a survey of tourists, we test four hypotheses to establish different components of intra-organizational learning on market orientation. We discuss these findings, and directions for future research.
\end{abstract}

\section{Keywords}

Intra-Organizational Learning, Market Orientation, Company Performance, Structure Equation Modeling

\section{Introduction}

While research on market orientation is abundant in marketing literature, researchers in hospitality and tourism economics have explored this area in a very limited way [1]. Consequently, there is only a handful of literature investigated phenomena related to culture of market orientation in tourism sector, much less different components of market orientation. Within this limited number of studies, research done by Au \& Tse [2] found contrary result where they showed that market orientation culture has negative impact on performance economics 
of hospitality companies. Tse, Sin, Yau, Lee [3] have justified these findings as the effect of economic boom when firms performance is not affected by their being market oriented as the demand will be always high, however, they have not explained the intuition of getting negative correlation since an economic boom can only make the relation between market orientation and hotel's performance insignificant, not always negative [4].

Tourism and hospitality companies spend considerable financial and human resource to be market oriented. Previous research on market orientation in tourism and hospitality sector has primarily studied relationship between market orientation and firms performance [5] [6]. While some previous literatures in hospitality and tourism sector have studied the relationship between market orientation and firm success, however, research studying impact of organizational learning market orientation of tourism and hospitality service providing companies is limited [1] [7]. Such study is further scares in the context of developing economy [8] [9] [10]. Till date only a handful of studies have examined the relationship between market orientation and firm success in different contexts [11]. None of these studies have considered intra-organizational learning namely information gathering, information dissemination, responsiveness and assessing the current and future need of the customers, and consequently their effect on firm's market orientation [12] [13].

Specifically, primary research issue of this paper is to study the set of relationships between intra-organizational learning and market orientation in the context of emerging economies like India's hospitality and tourism business. We have chosen India's hospitality and tourism industry as evidenced by increasingly competitive intensity and market dynamism, on the market orientation-business performance relationship. This study can be replicated in similar emerging economies where companies are yet to equip themselves with proper organizational learning systems. This study is designed to contribute further to existing literature in tourism and hospitality industry in a couple of ways: firstly, it investigates the market orientation of hospitality and tourism companies based upon their degree of market orientation and intra-organizational learning methods and secondly, this study has adopted multi-facet intra-organizational learning indicators with relation to market orientation. Additionally, the study enriches our knowledge of market orientation in hospitality and tourism industry of a developing economy, which has been of a great interest to researchers and managers alike.

\section{Literature and Hypothesis Development}

Researchers in marketing and tourism area tried to investigate the effect of market orientation on the profitability of the business in general [14] [15] and in tourism and hospitality sector in particular [16] [17]. Human capital is considered as firm's resource which produces customer value and consequently competitive advantage to hospitality and tourism companies [18]. Efficiency of hu- 
man capital depends upon education of employees, their experience both in and outside their job [19]. Though numerous studies have concluded that human capital is related to success, there is paucity of research that have examined the effect of intervening constructs on the human capital-success relationship [20]. In the hospitality context, Nieves and Quintana [21] reported that human capital has mediated the relationship between HRM training/development and IT practices and innovation. In another study, Lee et al. [1] reported that innovation activities and entrepreneurial self-efficacy fully mediate the influence of human capital on restaurant performance. Small ventures such as independent restaurant operations are formed around the persona of the individual owner/operator [22]. According to human capital theory, the task-related knowledge, skills, qualifications and experience of the restaurant entrepreneur is likely to be a prime source of critical resources that influence organizational outcomes. Previous research in the hospitality context suggests that HC is one of the most important resources available to industry practitioners [23].

Research literature has investigated relationships between market orientation and firm's performance [24], there are several issues that explains learning ability of the organization. First, the linkage between organizational learning [25], organizational knowledge [26], and Resource Based View (RBV) literatures [27]. This has in turn leaded the author to investigate the role of intra-organizational learning as key constructs on the relationships between market orientation and performance. Although such study calls for understanding the specific organizational conditions to understand intra-organizational learning, little research has investigated internal factors that influence this relationship [28]. There is growing theoretical and empirical evidence on the role of firm' learning and the positive effects it creates for organization and organizational knowledge transfer. Hence, focusing on intra-firm learning can identify effective positive and negative factors to the successful implementation of market orientation and thus help tourism managers to frame their strategy better way.

Day [29] examined that how capabilities in an organization can help in attaining market orientation. Slater and Narver [11] argued that the ability to learn faster that the competitors can add to the competitive advantage. If the organization has the ability to learn faster than the competitors then the organization would be able to notice the changes taking place. Due to this the organization would be in a position to maintain or increase the value delivered to the customers. In other words the organization which is capable of learning can deliver superior customer value. Learning ability of the organization can be considered as part of the capabilities of the organization [30]. Therefore learning ability can be considered as a part of organizational capabilities. Now as capabilities or more specifically ability to learn can help an organization to deliver superior customer value therefore it can be said that learning ability adds to market orientation of the organization. As shown in Figure 1, based upon this discussion the following hypotheses are stated: 
$\mathrm{H1}$ : The greater the teaching commitment of supervisor to her team members, higher the market orientation culture of tourism companies.

$\mathrm{H} 2$ : The greater the learning commitment of team members from their supervisor, higher the market orientation culture of the tourism company.

$\mathrm{H} 3$ : The greater the information flow between supervisor and his team member, higher the market orientation culture of the tourism companies.

$\mathrm{H} 4$ : The stronger the market orientation culture, higher the performance of the tourism company.

\section{Method}

A questionnaire containing questions of the key constructs for the study where developed. A total of 203 survey responses where collected from middle level managers working in marketing function of hospitality and tourism industry. A total of 264 executives were surveyed for usable response of 203. The survey was conducted with executives judgmentally selected by the researcher. Participants of the program were selected through a selection process of the institute. Average experience of male responded constituting $82 \%$ of the sample was 8.54 years. The managerial experience of the respondents who fulfilled the survey in the focal organization had an average of 5.47 years. Fifty six percent of them work in hospitality sector and $44 \%$ work in tourism sector. The survey instrument contained seven point Likert type scale items pertaining to the hypothesized constructs, including the independent and dependent constructs, in addition to background questions. In the questionnaire we have married the response format both for the items measuring dependent and independent constructs so that common method variance could be reduced. Description of all scale questions including the questions pertaining to the items retail after confirmatory factor analysis is provided in Table 1 .

As per the findings presented in Table 1, all constructs in the study provide excellent model fit with high degrees of convergent and discriminant validity. All fit indices are acceptable with $\mathrm{CMIN} / \mathrm{DF}=1.457, \mathrm{CFI}=0.97$;FI $=0.97$; PCFI $=$

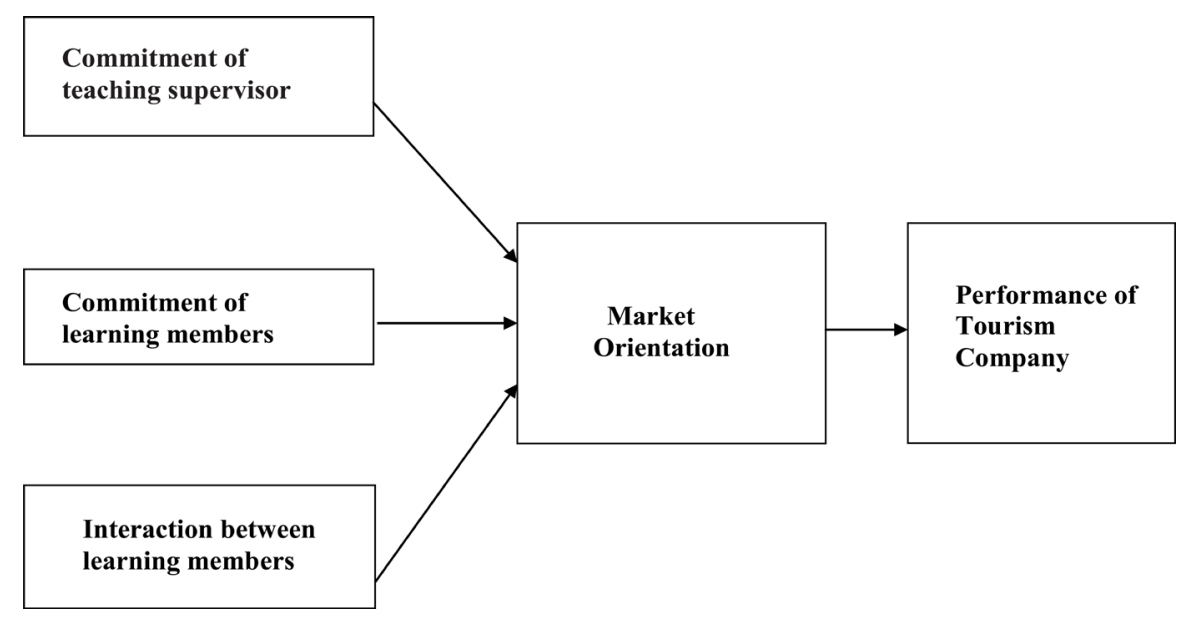

Figure 1. Conceptual framework. 
Table 1. CFA for measurement model in the study.

\begin{tabular}{|c|c|c|c|c|}
\hline Item & $\begin{array}{l}\text { Fit Indices for CFA: CMIN } / \mathrm{df}=1.347 \\
\qquad \mathrm{CFI}=0.97 ; \mathrm{IFI}=0.97 \\
\qquad \mathrm{PCFI}=0.827 ; \text { RMSEA }=0.041 \\
\text { Question }\end{array}$ & $\begin{array}{l}\text { Factor } \\
\text { Loading }\end{array}$ & $\begin{array}{l}\text { Construct } \\
\text { Reliability } \\
\text { (CR) }\end{array}$ & $\begin{array}{l}\text { AVE (Average } \\
\text { variance } \\
\text { Extracted) }\end{array}$ \\
\hline & Commitment of Teaching Supervisor & & 0.86 & 0.60 \\
\hline CTS1 & $\begin{array}{l}\text { My superior explains us what knowledge and skills will be needed to serve the customer } \\
\text { better }\end{array}$ & 0.823 & & \\
\hline CTS2 & $\begin{array}{l}\text { My superior does discusses with us about information gathered about customer and } \\
\text { market needs. }\end{array}$ & 0.768 & & \\
\hline CTS3 & I as a superior analyze important market information with my team members & 0.812 & & \\
\hline \multirow[t]{2}{*}{ CTS4 } & $\begin{array}{l}\text { Superiors in my organization are committed to make everyone aware about customer } \\
\text { and market information }\end{array}$ & 0.698 & & \\
\hline & Commitment of Learning Members & & 0.89 & 0.68 \\
\hline CLM1 & I put in endeavor to improve my knowledge about customers and market & 0.815 & & \\
\hline CLM22 & I am enthusiastic about collecting information about customers and market on my own & 0.837 & & \\
\hline CLM3 & I provide analysis of customer and market information to my superior & 0.820 & & \\
\hline \multirow[t]{2}{*}{ CLM4 } & I prefer regular meeting to discuss about customers and market & 0.822 & & \\
\hline & Interaction between Learning Members & & 0.83 & 0.56 \\
\hline ILM1 & Company staffs always discuss their official information among themselves. & 0.837 & & \\
\hline ILM2 & I put in great deal of effort to discuss market information with my peers & 0.658 & & \\
\hline ILM3 & Employees in my company behave quite friendly with their peers & 0.885 & & \\
\hline \multirow[t]{2}{*}{ ILM4 } & I put in endeavor to improve my interaction with my peers & 0.583 & & \\
\hline & Market Orientation & & 0.81 & 0.51 \\
\hline MO1 & $\begin{array}{l}\text { We extrapolate key trends to gain insight into what users in a current market will need } \\
\text { in the future. }\end{array}$ & 0.741 & & \\
\hline MO2 & $\begin{array}{l}\text { We search for opportunities in areas where customers have a difficult time expressing } \\
\text { their needs }\end{array}$ & 0.748 & & \\
\hline $\mathrm{MO} 3$ & We brainstorm on how customers use our products and services. & 0.680 & & \\
\hline \multirow[t]{2}{*}{$\mathrm{MO} 4$} & $\begin{array}{l}\text { We continuously try to discover additional needs of our customers of which they are } \\
\text { unaware }\end{array}$ & 0.705 & & \\
\hline & Firm Performance & & 0.87 & 0.64 \\
\hline FP1 & Financial performance of my company has improved considerably in last three years & 0.852 & & \\
\hline FP2 & Customers are increasingly more satisfied with your company's service than before & 0.741 & & \\
\hline FP3 & Employee turnover in my company has reduced considerably in last three years & 0.864 & & \\
\hline FP4 & Channel partners/suppliers of my company are performing better in last three years & 0.811 & & \\
\hline FP5 & Overall performance of the company has improved significantly & 0.731 & & \\
\hline
\end{tabular}

0.827; RMSEA = 0.041 (Williams, Vandenbergh, and Edwards, 2009). We present the Average Variance Extracted (AVE), construct reliability, and factor loadings for the constructs and the relevant items in Table 1. We have checked the convergent validity using average variance extracted. If the value of average variance extracted was greater than 0.5 we concluded the construct satisfies convergent 
validity. We have checked the discriminant validity by comparing the square root of the average variance extracted of each of the latent constructs with the cross construct correlations. If the square root of the AVE was greater than the corresponding cross construct correlations we concluded that the construct satisfy the discriminant validity requirement. We followed Fornell and Larcker's [31] method to establish discriminant validity.

\section{Results of the Structural Model}

We have used AMOS 18 package of SPSS in the structure equation modelling to test the hypotheses. We have first developed 3 learning related construct as exogenous construct which were measured by indicators mentioned in Table 1 .

Table 2 provides the result of structure model. We can see from the result that the feet indices satisfy the required criteria at the model shows an excellent feet to the data $(\mathrm{CMIN} / \mathrm{DF}=1.885$; CFI $=0.922$, IFI $=0.923$, PCFI $=0.799$, RMSEA $=0.066$ ) (Williams et al., 2009) with all of the fit indices in the acceptable range. First hypotheses $\mathrm{H}_{0}$ and $\mathrm{H} 2_{0}$ are rejected as there were enough evidence against the null hypotheses and we supported both alternate hypotheses. But $\mathrm{H}_{3}{ }_{0}$ is not rejected as data did not provide enough evidence to reject $\mathrm{H}_{0}{ }_{0}$. We find that teaching commitment of supervisor $(\beta=0.149, \mathrm{p}<0.05)$ and learning commitment of team members $(\beta=0.187, \mathrm{p}<0.05)$ is positively and significantly related to market orientation. However, we found that information collection difficulty has no significant effect on market orientation. We Next, as predicted rejected the null hypothesis $\mathrm{H}_{4}$ and found that market orientation has strong and significant effect on performance of tourism companies $(\beta=0.303, \mathrm{p}<0.01)$.

\section{Discussion and Conclusion}

Result from the data analysis shows strong support of the significance of effect of three constructs or intra organizational learning or decision variable, market orientation and subsequently the final variable performance of tourism firms in the context of an emerging market such as India. The main contribution of this research is conceptualization and development of impact of intra organizational learning construct, which has evolved from the capability based view of the firm. No significant research available identifying intra organizational learning as critical construct studies of knowledge transfer in tourism literature. Despite noting the importance of organizational learning and organizational capabilities, the market orientation literature has not conceptualized internal organizational

Table 2. Fit indices of structural model.

\begin{tabular}{cc}
\hline CMIN/DF & 1.885 \\
CFI & 0.922 \\
IFI & 0.923 \\
PCFI & 0.799 \\
RMSEA & 0.066 \\
\hline
\end{tabular}


characteristics that can facilitate effective implementation of market orientation [32] [33]. Following calls in the literature for examining internal organizational factors, this study has successfully identified, theoretically conceptualized, and empirically demonstrated how and why intra-firm learning processes effect market orientation leading to crucial performance outcomes of tourism companies. In this context, our conceptualization of the intra-organizational learning on the relationship between market orientation and business performance is a crucial theoretical contribution. Market orientation makes demands on the entire range of learning and knowledge processes in the organization for customer orientation, competitor orientation, and inter-functional coordination in generating a response to the market. More importantly, researchers have not leveraged the organizational learning and resource-based literatures to identify critically appropriate constructs to examine in this context, as we have done here. We identified intra-firm learning as it is a core construct in the resource-based view of the firm, in addition to the specific role it plays in knowledge transfer.

Findings of the study suggest that "teaching commitment of supervisors" and "learning commitment of team members" are positively related to market orientation. The result suggests that hospitality and tourism companies should not only gather information from the market and their customer, an efficient and structured intra-organizational learning mechanism is essential for tourism companies to be market oriented. Such intra-organizational learning mechanism will help the companies to disseminate market information to ground level managers who will, in turn, effectively coordinate with their field staffs to provide customer value.

We found no significant effects of "interaction between learning members" on market orientation. This could be because employees in tourism sector are self-driven, and primarily manage their own tasks on their own. For instance, there would be one tour guide for an entire tour, nullifying effect of group dynamics on market orientation. Moreover, it may be also possible that large number of employees may act as deterrent for others to carry forward the learning and self-improvisation. The accountability of each employee may decrease resulting insignificant to negative effect on market orientation.

A market oriented tourism company is required to inculcate a sort of intra-organization learning culture, nurture such culture which fosters interdepartmental coordination [34]. Future research may look at these directions [35]. It goes usually way beyond understanding of the fact that market orientation is not the sole responsibility of marketing department and generation and dissemination of information regarding the customers and competitors involve an intra-organizational coordination.

\section{References}

[1] Lee, Y.K., Kim, S.H., Seo, M.K. and Hight, K.S. (2015) Market Orientation and Business Performance: Evidence from Franchising Industry. International Journal of Hospitality Management, 44, 28-37. https://doi.org/10.1016/j.ijhm.2014.09.008 
[2] Au, A.K. and Tse, A.C. (1995) The Effect of Marketing Orientation on Company Performance in the Service Sector: A Comparitive Study of the Hotel Industry in Hong Kong and New Zealand. Journal of International Consumer Marketing, 8, 77-87. https://doi.org/10.1300/J046v08n02_06

[3] Tse, A., Sin, L., Yim, F. and Heung, V. (2005) Market Orientation and Hotel Performance. Annals of Tourism Research, 32, 1145-1147. https://doi.org/10.1016/j.annals.2004.08.006

[4] Tajeddini, K. (2011) Customer Orientation, Learning Orientation, and New Service Development: An Empirical Investigation of the Swiss Hotel Industry. Journal of Hospitality \& Tourism Research, 35, 437-468. https://doi.org/10.1177/1096348010380599

[5] Grissemann, U., Plank, A. and Brunner-Sperdin, A. (2013) Enhancing Business Performance of Hotels: The Role of Innovation and Customer Orientation. International Journal of Hospitality Management, 33, 347-356. https://doi.org/10.1016/j.ijhm.2012.10.005

[6] Campo, S., Díaz, A.M. and Yagüe, M.J. (2014) Market Orientation in Mid-Range Service: Urban Hotels: How to Apply the MKTOR Instrument. International Journal of Hospitality Management, 43, 76-86. https://doi.org/10.1016/j.ijhm.2014.08.006

[7] Harris, L.C. (2001) Market Orientation and Performance: Objective and Subjective Empirical Evidence from U.K. Companies. Journal of Management Studies, 38, 17-43. https://doi.org/10.1111/1467-6486.00226

[8] Adhikari, A. and Gill, M.S. (2012) Impact of Resources, Capabilities, and Technology on Market Orientation of Indian B2B Firms. Journal of Services Research, 11, 75-98.

[9] Ikwueze, L.C. (2014) Linking Market Internality to the Non-Oil Sector in Nigeria. Theoretical Economics Letters, 4, 190. https://doi.org/10.4236/tel.2014.43027

[10] Lakshman, C., Kumra, R. and Adhikari, A. (2017) Proactive Market Orientation and Innovation in India: The Moderating Role of Intrafirm Causal Ambiguity. Journal of Management \& Organization, 23, 116-135. https://doi.org/10.1017/jmo.2016.11

[11] Narver, J.C. and Slater, S.F. (1990) The Effect of Market Orientation on Business Profitability. Journal of Marketing, 53, 20-35. https://doi.org/10.2307/1251757

[12] Watkins, L. and Gnoth, J. (2011) The Value Orientation Approach to Understanding Culture. Annals of Tourism Research, 38, 1274-1299. https://doi.org/10.1016/j.annals.2011.03.003

[13] Hult, G.T.M., Ketchen, D.J. and Slater, S.F. (2005) Market Orientation and Performance: An Integration of Disparate Approaches. Strategic Management Journal, 26, 1173-1181. https://doi.org/10.1002/smj.494

[14] Slater, S.F. and Narver, J.C. (1995) Market Orientation and the Learning Organization. Journal of Marketing, 59, 63-74. https://doi.org/10.2307/1252120

[15] Peña, A.I.P., Jamilena, D.M.F. and Molina, M.Á.R. (2013) Impact of Customer Orientation and ICT Use on the Perceived Performance of Rural Tourism Enterprises. Journal of Travel Tourism Marketing, 30, 272-289. https://doi.org/10.1080/10548408.2013.774921

[16] Sin, L.Y., Tse, A.C., Chan, H., Heung, V.C. and Yim, F.H. (2006) The Effects of Relationship Marketing Orientation on Business Performance in the Hotel Industry. Journal of Hospitality \& Tourism Research, 30, 407-426. 
https://doi.org/10.1177/1096348006287863

[17] Bigné, J.E., Andreu, L., Küster, I. and Blesa, A. (2005) Quality Market Orientation: Tourist Agencies' Perceived Effects. Annals of Tourism Research, 32, 1022-1038. https://doi.org/10.1016/j.annals.2005.07.001

[18] Nyberg, A.J., Moliterno, T.P., Hale Jr., D. and Lepak, D.P. (2014) Resource-Based Perspectives on Unit-Level Human Capital: A Review and Integration. Journal of Management, 40, 316-346. https://doi.org/10.1177/0149206312458703

[19] Unger, J.M., Rauch, A., Frese, M. and Rosenbusch, N. (2011) Human Capital and Entrepreneurial Success: A Meta-Analytical Review. Journal of Business Venturing, 26, 341-358. https://doi.org/10.1016/j.jbusvent.2009.09.004

[20] Davidsson, P. and Honig, B. (2003) The Role of Social and Human Capital among Nascent Entrepreneurs. Journal of Business Venturing, 18, 301-331. https://doi.org/10.1016/S0883-9026(02)00097-6

[21] Nieves, J., Quintana, A. and Osorio, J. (2016) Organizational Knowledge, Dynamic Capabilities and Innovation in the Hotel Industry. Tourism and Hospitality Research, 16, 158-171. https://doi.org/10.1177/1467358415600208

[22] Cooper, A.C., Gimeno-Gascon, F.J. and Woo, C.Y. (1994) Initial Human and Financial Capital as Predictors of New Venture Performance. Journal of Business Venturing, 9, 371-395. https://doi.org/10.1016/0883-9026(94)90013-2

[23] Sainaghi, R., Phillips, P. and Corti, V. (2013) Measuring Hotel Performance: Using a Balanced Scorecard Perspectives' Approach. International Journal of Hospitality Management, 34, 150-159. https://doi.org/10.1016/j.ijhm.2013.02.008

[24] Wang, C.H., Chen, K.Y. and Chen, S.C. (2012) Total Quality Management, Market Orientation and Hotel Performance: The Moderating Effects of External Environmental Factors. International Journal of Hospitality Management, 31, 119-129. https://doi.org/10.1016/j.ijhm.2011.03.013

[25] Kohli, A.K. and Jaworski, B.J. (1990) Market Orientation: The Construct, Research Propositions, and Managerial Implications. The Journal of Marketing, 54, 1-18. https://doi.org/10.2307/1251866

[26] Jaworski, B.J. and Kohli, A.K. (1993) Market Orientation: Antecedents and Consequences. Journal of Marketing, 57, 53-70. https://doi.org/10.2307/1251854

[27] Karatepe, O.M. and Douri, B.G. (2012) Does Customer Orientation Mediate the Effect of Job Resourcefulness on Hotel Employee Outcomes? Evidence from Iran. Journal of Hospitality and Tourism Management, 19, 133-142. https://doi.org/10.1017/jht.2012.15

[28] Atuahene-Gima, K. (2005) Resolving the Capability-Rigidity Paradox in New Product Innovation. Journal of Marketing, 69, 61-83. https://doi.org/10.1509/jmkg.2005.69.4.61

[29] Day, G. (1994) The Capabilities of Market-Driven Organizations. Journal of Marketing, 58, 37-52. https://doi.org/10.2307/1251915

[30] Adhikary, M. and Adhikari, A. (2017) Micro-Modelling of Individual Tourist's Information-Seeking Behaviour: A Heterogeneity-Specific Study. Current Issues in Tourism, 1-24. https://doi.org/10.1080/13683500.2017.1307816

[31] Fornell, C. and Larcker, D.F. (1981) Structural Equation Models with Unobservable Variables and Measurement Error: Algebra and Statistics. Journal of Marketing Research, 18, 382-388. https://doi.org/10.2307/3150980

[32] Aggarwal, N. (2003) Organizational Barriers to Market Orientation: An Indian Experience. Journal of Management Research, 3, 87-97. 
[33] Amelot, L.M.M., Ushad, S.A. and Lamport, M. (2017) Testing the Efficient Market Hypothesis in an Emerging Market: Evidence from Forex Market in Mauritius. Theoretical Economics Letters, 7, 2104. https://doi.org/10.4236/tel.2017.77143

[34] Grewal, R. and Tansuhaj, P. (2001) Building Organizational Capabilities for Managing Economic Crisis: The Role of Market Orientation and Strategic Flexibility. Journal of Marketing, 65, 67-80. https://doi.org/10.1509/jmkg.65.2.67.18259

[35] Ren, D. (2016) Research on the Dilemma of Speculation in Chinese Stock Market Based on Game Theory. Theoretical Economics Letters, 6, 678.

https://doi.org/10.4236/tel.2016.64072 